CATALAN REVIEW

Catalan Review

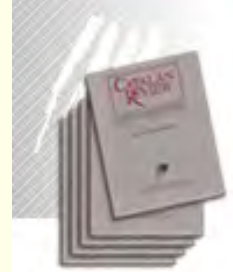

You are accessing the Digital Archive of the Catalan Review Journal.

By accessing and/or using this Digital Archive, you accept and agree to abide by the Terms and Conditions of Use available at http://www.nacs-

catalanstudies.org/catalan review.html

Catalan Review is the premier international scholarly journal devoted to all aspects of Catalan culture. By Catalan culture is understood all manifestations of intellectual and artistic life produced in the Catalan language or in the geographical areas where Catalan is spoken. Catalan Review has been in publication since 1986.
NORTH

AMERICAN

CATALAN

SOCIETY
Esteu accedint a l'Arxiu Digital del Catalan Review

A l' accedir i / o utilitzar aquest Arxiu Digital, vostè accepta i es compromet a complir els termes i condicions d'ús disponibles a http://www.nacs-

catalanstudies.org/catalan review.html

Catalan Review és la primera revista internacional dedicada a tots els aspectes de la cultura catalana. Per la cultura catalana s'entén totes les manifestacions de la vida intel lectual i artística produïda en llengua catalana o en les zones geogràfiques on es parla català. Catalan Review es publica des de 1986.

\title{
The Catholic Church in Catalonia. From Cataclysm in the Civil War to the "Euphoria" of the 1950s Andrew Dowling
}

Catalan Review, Vol. XX, (2006), p. 83-100 


\title{
THE CATHOLIC CHURCH IN CATALONIA. FROM CATACLYSM IN THE CIVIL WAR TO THE“EUPHORIA" OF THE I95Os
}

\author{
ANDREW DOWLING
}

\section{ABSTRACT}

In the summer of 1936 , with the beginning of the Spanish Civil War, the Catalan Church underwent a ferocious assault, without precedent in modern European history. Catalan society in the early decades of the twentieth century had been divided over its relationship to the Catholic Church, with some sectors being profoundly anti-clerical. Yet by the early ig 60 , attitudes towards the Catholic Church had changed. This article is concerned with reconstructing Catalan and Catalanist Catholicism from one of profound crisis during the Civil War to its re-emergence from the confines of Spanish National Catholicism. Francoist victory in the Spanish Civil War meant the ending of indigenous Catholic traditions. However, from the mid-1940s we can trace the slow reconstruction of Catalan traditions, language and culture. All of the major expressions of Catalan identity until the 1960 s were enabled due to this Catholic patronage. Whilst the Church was unable to reverse secularization trends, this involvement in cultural activity would transform its place within wider Catalan society. By the end of the period examined in this article, historic and deep rooted anti-clericalism in Catalonia was ending.

In July 1936, on the outbreak of the Spanish Civil War, the Catalan Church underwent a ferocious assault, without precedent in modern European history. One third of the religious killings that took place in Spain during the Civil War occurred in Catalonia. In fact, it is no exaggeration to state that, in proportionate terms, Catalonia experienced the greatest anti-religious outbreak in modern European history. As will be seen, Francoist victory in the Civil War gave the Church a perhaps unique opportunity, not only to restore its position, but to become a part of the Francoist triumvirate of power, in alliance with the Falange and the military. However, this restoration would give the Church an opportunity to become not only central to the Catalan nation, but to play an important role in the reconstruction and revival of Catalanism.

The Church had been involved in the late nineteenth-century formulation of conservative Catalanism. However, the Catalanism that emerged on the left became expressed through Republicanism, a movement that contained within it a discourse of anti-clericalism. The anti-clerical riots of the Tragic Week of 1909 were an early demonstration 
that the position of the Church was greatly threatened amongst the urban masses in Catalonia (Connelly Ulmann 329). The Catalan Church would largely retain its influence in rural Catalonia but the next quarter century demonstrated that most urban areas were lost to it and, in particular the city of Barcelona. Throughout this period there were debates in the Church as to how to end the process of secularization. One response lay behind the foundation of the monthly $\mathrm{La}$ paraula cristiana by Canon Carles Cardó which sought a "liberal" turn on the part of the Church to reach the atheist and irreligious sectors of the population. ${ }^{\mathrm{I}}$ Cardó called for activism: "Any decades more of abstention and in our Catalonia, Catholicism would be nothing more than a memory" (La paraula cristiana 3 ). As will subsequently be seen, the Franco regime would provide the greatest opportunity to the Church to undertake its program of re-Christianization. Re-Christianization as ideology and strategy represented an attempt by the Church in Catalonia to reverse the forces of secularization and anticlericalism that had become deeply embedded in the culture.

The successful fusion of Catalanist Republicans into one party, Esquerra Republicana de Catalunya at the beginning of the Spanish Second Republic (193I) would mean that the Church's influence amongst the political class would decline as the Catalan autonomous government, the Generalitat, came to be governed by liberal Catalanists. The Church would suffer a double displacement. It was closest politically to the Lliga Regionalista, itself discredited by its support for Primo de Rivera's dictatorship (1923-1930). Secondly, the onset of the Republic would bring forward a new political class of largely secular modernizers, who saw the Church as an agent of backwardness and as a barrier to "progress." The Church's position in Catalan society appeared to be negated by both "liberals" and revolutionaries in Catalonia.

During the course of the Republic, the Lliga continued to see itself as defender of the Church. The Lliga-led Front Català d'Ordre, the reactionary coalition created to fight the February 1936 election, made the Catholic religion one of its principal banners of propaganda (Garcia Jordan 133).

The attempted military coup of July 1936 failed in Catalonia and its defeat resulted in a radicalization of the CNT-led working class and the subsequent outbreak of revolution. One consequence of this revolution was the assassination of over 2,000 priests and members of

I Canon Carles Cardo worked closely with the Bishop of Tarragona, Francesc Vidal $\mathrm{i}$ Barraquer, in an attempt to create greater distance by the Catalan Church from Spanish ultra-reactionary Catholicism, seen as particularly counter-productive in the case of the city of Barcelona, with both strong worker and Catalanist traditions. 
religious orders (Solé i Sabaté and Villarroya La repressió 179). ${ }^{2}$ The killings were accompanied by a sustained attack on the buildings of the Catholic Church. What occurred in Catalonia was a veritable pogrom against Catholicism. Some explanation of why it was the Catholic Church that was attacked with such vehemence is obviously required. It was noted in 1938 that in "certain churches political sermons against liberalism and socialism had been preached during the election (of 1936), particularly in Barcelona" (Parliamentary Committee 22). It is commonly held to be the case that anarchism in Catalonia bears the primary responsibility for the attack on the Church.

Strikingly, it was not until one month after the outbreak of Civil War, with news of the atrocities committed within Nationalist controlled Spain, as the drive on Madrid proceeded, that the fiercest attack on the Church took place. That is, following a month of largely spontaneous attacks. In a front page editorial entitled "Down with the Church," the anarchist daily, Solidaridad Obrera, declared, "Thirty centuries [sic] of religious obscurantism have poisoned the minds of the Spanish people. The priest, the friar and the Jesuit ruled in Spain. These people have to be eradicated." Hostility was not without a class component: "Bishops and Cardinals have to be shot" (jAbajo la Iglesia! I). Amongst the factors that contributed to popular anticlericalism was the belief in the "horrors" that took place in convents, where it was believed that unmarried pregnant women were mummified alive (Pérez Ledesma 231). The Church was believed to hold great wealth (anarchists claimed to have discovered the enormous sum of 17 million pesetas from the churches in Vic) ("Dieciséis millones" I). Other contributory factors were the existence of deeply rooted anti-clericalism since the Middle Ages; the anti-clerical riots and attacks on the Church in the nineteenth century (Esdaile 59, 70); the events of the Tragic Week of 1909 and the discourse of the radical republicanism known as Lerrouxisme. Furthermore, as Jaume Barrull has demonstrated for Lleida, where $65 \%$ of the priests were murdered, there were "no urban masses nor any libertarian tradition" (Barrull Pelegrí 36-40). All of which are a reminder that anarchism fed on already existing Catalan anti-clerical traditions.

After the revolution and the wave of anti-clerical killings, it is perhaps not surprising that the Church in Catalonia saw its only hope of salvation, indeed its very continuance, in the victory of the Spanish Nationalists. However, in spite of the traumatic position of the Church in Catalonia, it was viewed with suspicion by the Francoists. A San Sebastián newspaper declared: "Although to a lesser extent than in the Basque Country, in Catalonia there also existed a group of false

2 Their figure is 2039 . 
Catholics inclined to serve tribal nationalism at the expense of the Church" (Sole i Sabaté and Villarroya L'ocupació 32). The choice between Franco and the "incontrolats," 3 the Catalan Church chose Franco. Two of the principal promoters of the idea that the Civil War was a "religious crusade" were two Catalan Bishops, Isidre Gomá and Enric $\mathrm{Pla}$ i Daniel, representative of an ultra-conservative tradition within Catalan Catholicism. The Bishop of Tarragona, Francesc de Asís Vidal i Barraquer, was representative of another tradition and opposed the Spanish bishops collective pastoral of July 1937 as he believed it would be counter-productive for the Church to associate itself so directly with the Francoists and he feared the consequences for Catholics in "Red" territory. The consequences of his opposition were marginalization by the Spanish hierarchy and life that would end in exile.

During the first months of the Civil War in Catalonia, there had emerged a system of parallel government. However, the events of May 1937 in Barcelona instituted the restoration of state power in Catalonia (Graham 53I). This victory permitted the cautious restoration of Catholic activity in Catalonia (Manent i Segimon and Raventós i Giralt. 97--124).

With Franco's victory in the Civil War, the Catholic Church was restored to power on the wave of National Catholicism that reigned throughout the 1940s and 1950s. This ideology was above all "antimodern," it was the theology of the Reconquest (Piñol 86, Alvárez Bolado 195). As one Church commentator has noted: The Catholic Church remained silent on the terror that was institutionalized as construction of the New State proceeded apace. As Bada has noted, "At no moment... did the Episcopacy of Catalonia nor any of its members raise the subject of the repression" (I20).

For at least the early years of the dictatorship, the regime could count on the support, whether active or passive, of Catholic bourgeois and the Church. Sectors of Catalan society that would be the bulwark of the regime elsewhere in Spain would, however, later become Catalanist centers of opposition to it. The Franco regime was initially welcomed after the profound trauma of the Civil War. The profundity of the cataclysm for the Church left it reeling, unable to comprehend what had befallen it. As one Catalan theologian asked, "Why did they not burn the Capitania General [military government]? Why did they not put the University of Barcelona to the torch? Why wasn't it the Colon hotel?... when people got inside these buildings they didn't think of burning them down"(Rucabado Iglesias 139).4 Some of the

3 Literally those "out of control," the term that came to be applied to those who had been most active in the attack on the Church.

4 See also La Custodia by the same author. 
prominent figures of pre-war liberal Catholicism, including Bishop Vidal i Barraquer and Canon Carles Cardó, initially believed that "salvation" for the Church would come with Franco. In fact, due to their liberalism and Catalanism, they remained in exile in the 1940s. Francoism was also determined to end Catalan religious exceptionalism. The Federació de Joves Cristians, reaching a membership of 18,000 in 1936, was one of many entities banned in the Francoist New State (La Federació 264).

After the traumas of the Civil War, the Church devoted itself to its own reconstruction, both spiritually and physically. In Catalonia the Church had more work to do than in any other area of the Spanish State in this twin process. Of the more than 6,000 members of religious orders executed throughout Spain, over a third had been killed in Catalonia. The Catalan Church suffered proportionately the fiercest anti-religious attack in all of twentieth century, indeed modern, European history. More than four thousand churches and other religious buildings were destroyed in Catalonia, of which over 220 were razed to the ground in two days alone. Religious life had been almost wiped out. The Bishop of Vic declared in February 1939: "Truly pathetic is the picture that presents itself before our eyes... unbaptized children; others spiritually undernourished having been deprived of the bread of the catechism; marriages without blessing; the dead without the sacraments; morality thrown to the ground, with vice enthroned" ("Después de la Liberación").

The decade of the I940s was marked by the enormous programs of building, rebuilding and the restoration of churches, with regular calls from the pulpit for financial help in this project. The open air and schools were used where there were no religious buildings available or while they awaited the blessing of the bishop of the diocese due to their profanation.

In this period the Church centered its attention on its program of re-Christianization. In February 194I, the Bishop of Vic emphasized the need "to re-Christianize the Spanish people, who have been poisoned by Marxist utopias and to return them to faith and patriotism... [the] secret of our imperial grandeur" (Bada 45). Francoist victory not only restored the Catholic Church but gave it unprecedented power and influence over society. The Church became the arbiter of control over morality and an agency of social control. Strong Catalan anti-clerical traditions were crushed in the immediate aftermath of the Civil War and an attempt was made to displace them with the moral hegemony of National Catholicism. The urgency to the program of re-Christianization was made glaringly apparent in a survey conducted for Acción Católica in 1941 on religious belief amongst workers aged between fourteen and thirty-five in the diocese 
of Barcelona. To the dismay of the faithful, it found that not more than three per cent of workers defined themselves as Catholics: "That horrifying $97 \%$ means that all young people are in terrible danger of disaster...distracted by the cinema, dances, pornography and evil friends" (" $\mathrm{r}$ " Jornada de Estudios Obrera"). If the "flock" was in danger, the position of the "shepherds" was, for the Church, equally traumatic. Thirty per cent of the priests of Catalonia had been killed in the war. The consequences of this situation are given expression by the following appeal made in the early days of the regime: "There is a pressing need...to which few have paid sufficient attention: that is the lack of priests... Leave a people fifty years without priests and they will worship the beasts" ("Mensaje a los seminaristas").5 Catholic priests returned to churches blackened by fire, with strong memories of the fate that had befallen their less fortunate colleagues. It would be several years before the trauma would lift and Catholic sectors would seek to revive indigenous Catholic traditions. Whatever the personal predilections of Catalan priests and laity towards the regime, what was undeniable was that their "salvation" and that of their religion came at the hands of Franco's forces:

The day arrived when Catalonia, victim of its own mistakes, found itself shipwrecked in the abyss of a revolution whose only aim was to scorn and destroy it... Today, Catalonia redeemed gives itself with fervor... to the fruitful task of material and spiritual resurgence and says to Franco: You saved me from a death without resurrection. (Homenaje de Cataluña $\mathrm{x}$ )

Services of thanksgiving for the "liberation" took place throughout Catalonia. At Montserrat a special service was given commemorating the Carlist requeté dead, who with the permission of Abbot Escarré, had been buried at the monastery. In 1942, in welcoming a visit of Franco to the monastery, the abbot declared: "We remember with thanks how, three years ago, under the impulse of your arms, the doors of our basilica were re-opened after having been closed for thirty months... [This meant that] we could begin again the splendid and traditional worship of our Black Madonna." Escarré also noted that Franco's victory permitted the monastery "to continue (its) cultural tasks" ("Discurso del abad mitrado" 3 ).

The assault on the Catalan Church had occurred from within Catalonia (in contrast to the Basque Country), yet its restoration came from without, through the military victory of Franco's troops. The Franco regime restored Catholicism, its price being the ending of Catalanism. It would, however, be the restoration of Catholicism that would permit the Church in Catalonia not only to revive Catalanism

5. See also "La necesidad de fomenter las vocaciones." 
but to shape its reformulation. Whilst the Catalan clergy and faithful welcomed being able to practice their religion again, resentment would grow over time at the nature of the imposition of Spanish National Catholicism and that this spirit did not emanate from within indigenous Catalan traditions. As the innumerable projects of reconstruction approached their completion, sectors of the Church began to concern themselves with their relationship with Catalan identity and in particular the Catalan language. In these sectors, Josep Torras i Bages was seen as the founding father of Catholic Catalanism. Torras $i$ Bages had led clerical involvement in the emergent movement of Catalanism in the late nineteenth century. The revival of Torras's thought took place under Franco as he became an icon for the Catholic Catalanists and for other groups of Catholics within Catalonia. As one observer put it in the late 1940 , "Much of what is Vic today and much of the universality achieved by Balmes in the decades to follow...is due to the illustrious and greatly loved figure of Torras i Bages" (Llopis 2). One of the groups of the Catholic Catalanists was called appropriately enough the Grup Torras $i$ Bages, which was itself the predecessor to the group of the rasos known as CC, Crist i Catalunya or Catòlics Catalans. ${ }^{6}$

Bishop Torras i Bages greatly influenced the thought of Abbot Escarré who shared his messianic goal of a Christian Catalonia or, more accurately, a re-Christianized Catalonia. The Catalan Church shared the state's goal of re-Christianizing the population, yet it was considered particularly urgent in Catalonia because secularization was so advanced. The urban masses were not just secular but fervently anti-religious. However, as the population was still overwhelmingly Catalan speaking the imposition of religious services in Spanish further preoccupied the Catalan Church because it threatened to alienate those elements of Catalan society that had remained loyal to it. The Catalan Church could not afford to lose the support of the Catalan-speaking peasantry and middle-class. Spanish Catholic fundamentalism was therefore viewed in an ambivalent way because of this potential to alienate these Catalan Catholic sectors. Whilst they shared most elements of the Francoist state religious program, particularly the emphasis on re-Christianization of the population, the means chosen were strikingly different. The monastery of Montserrat would lead those Catholics that wanted this re-Christianization to be undertaken in the spirit of Catalan Church traditions.

In many studies of this period prominence is given to the events of April 1947 known as l'entronització de la Mare de Déu de Montserrat. It is sometimes referred to as "the first public manifestation of Cata- 
lanism" since the Civil War. 7 The origins of the event lie in the decision to pay homage to the Black Madonna through a religious ceremony of enthronement. The monastery is "the site of one of the longest continuous cults of the Virgin Mary" (Warner 274). 1947 was an international year of Marianism and the event at Montserrat took place in an already existing atmosphere of religious revivalism. The event's fundamental function was one of re-Christianization. ${ }^{8}$ The historic figures of Catalan Catholicism had themselves been revived in these years, 1945 had been celebrated as the centenary of Verdaguer and 100,000 copies of his works had been sold during the year ("Un record de librerias").? 1946 was the turn of Torras i Bages and 1948 was celebrated as the year of Balmes. ${ }^{10}$ The events of April 1947 have to be seen in the context of the revivalism and re-construction that was a product of the spiritual fervor of these years. In a pastoral letter, the Bishop of Barcelona noted that, in 1947 alone, $\mathrm{II} 3$ churches had been built and another thirteen were under construction (Circular de la Junta).

The Commissio Abat Oliba was the Montserrat-inspired organizing committee responsible for the mobilization. The Commissio was permitted by the Civil Governor of Barcelona to use the Catalan language for its campaign and leaflets were sent out to all Catalan parishes. This was a further demonstration of the recuperation of the language for religions purposes. From the mid-1940s, poems by Verdaguer and Maragall, poems dedicated to Torras i Bages or to the Black Madonna of Montserrat could be found in journals imbued with the theology of Spanish National Catholicism. " One of the organizers of l'entronització, Josep Benet, stated that the aim of the event was 'the reconquest of the Fatherland for Christ'. In the Commissio's bulletin it was added: "Everybody has to bear in mind that in the religious history of our people, the ceremonies have to be start of the spiritual

7 Amongst English language works, Hank Johnson's Tales of Nationalism and Daniel Conversi's The Basques and the Catalans. Alternative Routes to Nationalist Mobilisation attach a pivotal role to these events. Conversi erroneously states that Escarré became anti-Francoist in 1947, see Conversi, p. 128 .

8 See La Vangwardia and Avui, April 1997 for how the fiftieth anniversary was treated in the Catalan press. Catalan,

9 J.A.C.E., August 2945 . This edition includes substantial quotes of Verdaguer in

10 On the significance of the centenary of Torras i Bages see, Circular de la Junta Diocesana de Acción Católica, I November 1946. For Balmes see, Noticiario de la Unión Diocesana de Hombres de Acción Católica de Barcelona, is February, is March, is May and July-August 1948.

I1 Sce "Cirerer de claustre," "Goigs a llaor de Sant Cugat," "Jesuis Infant," "Nadal," "Neguit," "L'ombra del bisbe Torras," "Ombres i clavors" and "Vara Florida." 
renaissance and re-Christianization of the country" (Benet qtd in Grau 115$)^{12}$ The Catalan Church and broad sections of Catalan Catholicism, from the Catalanists to ultra-reactionaries within Spanish National Catholicism made their individual commitment to the Black Madonna on 27 April 1947. Although in later years, the events of l'entronització would attain mythic status, commissions participated throughout Spain, including Madrid ("Fiestas" 7). The Bishop of Tarragona declared: "It is the time of the glorification of the Virgin and it is also the time to ask God for his protection, to save and defend us from our enemies, who from inside Spain and without, conspire against the Christian faith" ("Pastoral del cardinal-arzobispo de Tarragona" ro). Abbot Escarré sent a personal telegram to Franco thanking him for his support over l'entronització and expressed his continued loyalty to the Caudillo ("Gratitud al Caudillo").

Whilst the nature of l'entronització has been subject to subsequent exaggeration, the event did give the Catholic Catalanists the first major boost in the reconstruction of an indigenous Catholicism. From early in the Franco regime it became clear that the only Catalanism that could be expressed, without immediate repression, would be through the Church. Permission for small scale publishing in Catalan had already been granted in the early 1940s, and significantly only on religious subjects. The first publication in Catalan was that by Monsignor Camil Geis in August 1942, an ecclesiastical work entitled Rosa Mistica. In November 1943 the complete works of Verdaguer were published. ${ }^{13}$ Another event of note at this time was the international Marian Congress of Barcelona of December 1947 ("Congregaciones Marianes”). In 1949, the millennial celebrations of Abbot Oliba were a further stimulus to Catalan-language religious revival. ${ }^{14}$ In September 1948, the Catalan language was used in a homily at Montserrat monastery for the first time, a usage that would continue thereafter. This religious usage of the Catalan language would become a launchpad for a pre-political program of a Catholic-led revival of cultural Catalanism.

The I950s produced indications of the challenges that the Franco

12 See also Circular de la Commissió Abat Oliba, November-December 1946 and March 1947. Somewhat bizarrely, Conversi describes Josep Benet as a 'left-wing secular nationalist', see Conversi, p.r27.

13 Jacint Verdaguer, religious poet and writer, was considered to be one of the central figures of the nineteenth century Catalan cultural renaissance, the Renaixença. Verse by Verdaguer in Catalan was published by the Barcelona weekly, Destino, as early as 22 February 194.

I4 J.A.C.E.,October 1947 and Noticiari, Confradia de la Mare de Dêu de Montserrat, September-October 1949. Abbot Oliba was the medieval founder of the monastery. 
regime would face in its final years: student opposition, a protesting and organizing working class and opposition from the Basque Country and Catalonia. The Catholic Church had as yet made no breach with the regime and it was during this decade that the Church achieved an enormous consolidation in its power and influence, a period that has been described as "the years of euphoria" (Bach 96, Perry and Echeverría 242). These years represent a period of Catholic cultural and moral hegemony. Catholic Catalanism used this situation to consolidate the small openings obtained in the 1940s. Some of the earliest attempts to break from the confines of Spanish National Catholicism and re-integrate into the mainstream of European Catholicism occurred in Catalonia.

An insight into the Church's growing engagement with the Catalan language and culture is revealed in an extensive correspondence between the civil governor of the province of Barcelona, General Acedo Colunga, and two figures of the central government in Madrid. The origins of the correspondence lie in a complaint directed personally to Franco by a disgruntled Rightist, Angel Escutia, who protested about the use of Catalan in Church services and the increased appearance of what he felt to be acts of a "separatist nature." "The days following 1939 seem so far away...the principle of authority is not as iron-fisted as it was then'. Escutia noted that 'the attitude of the lower clergy is very influential, because in this province [Barcelona], in almost all of the parishes, religious acts are celebrated using Catalan and Your Excellency can suppose the effect this causes amongst the faithful" (Escutia). In his response to enquiries from Madrid, Acedo Colunga reviewed the situation as he then saw it. $\mathrm{He}$ referred to "españolismo amongst the masses and even in the middle classes...There is no separatist Catalanism" (Letter to Franco SalgadoAraujo). ${ }^{15}$ In his correspondence with Blas Pérez, the minister in Madrid responsible for the civil governors, Acedo Colunga acknowledged "that there is an increase in preaching in Catalan...I am the first to be charmed by the sardana and I understand and respect the Catalan language, but naturally, the increase in the usage of Catalan for religious purposes and in other public arenas cannot be permitted." (Letter to Blas Pérez). Acedo announced that he was working in tandem with the Spanish Bishop of Barcelona, Gregorio Modrego, and that both had agreed to labor together to reverse the process of Catalanization. Acedo also commented on the notable rivalry that existed between Modrego and the Abbot of Montserrat. This personal rivalry symbolized the division between a Spanish hierarchy imbued with the values of National Catholicism and Escarré, who was 
increasingly distancing himself from an initial loyalty to the regime. Acedo further commented that it was his belief that about thirty-five to forty per cent of the clergy in Catalonia were Catalanist, "some of a moderate Catalanism, that can be thought of as regionalism, and others, though fewer, that exhibit an irritating nationalism" (Letter to Blas Pérez).

The significance of these comments for the regime is to be found in the problems inherent in disciplining the Church, as in the following year, 1952, the biennial celebration of world Catholicism, the International Eucharist Congress, was to take place in Barcelona. The fact that this Congress was to take place on Spanish soil was seen as a triumph for the regime and a further indicator of its increasing international acceptance. To make matters more complicated for the regime's attempts at controlling the Catalanization of the Church, the closing act of the Congress was to take place at Montserrat. The Moreneta or Black Madonna of Montserrat was also the patroness of the Congress, and in the official bulletin, the hymn of the Congress was printed in Catalan (Boletin Informativo). ${ }^{16}$

The first half of the twentieth century had seen the formation of a number of lay organizations, "all affecting a military style and all dedicated to winning the world for the Virgin Mary" and these too emerged in Catalonia (Carroll 2I). There were three principal Catalan Marian groups of the 1950 s that developed in the direction of Catalanism. Firstly, the Congregacions Marianes of the Jesuits, a body that in 1954 constituted the Acadèmia de la Llengua Catalana. A second group was the Confraria de la Mare de Déu de Montserrat, which was created in the mid-r94os and was based in the private school Virtèlia in Barcelona. The third sector was enrolled in the Lliga Espiritual de la Mare de Déu de Montserrat, which was a revival of the formation that had been created by Bishop Torras i Bages in 1899 . These organizations received a spiritual boost at the end of 1950 when Pope Pius XII proclaimed the doctrine of the Assumption of the Virgin Mary into heaven as part of Catholic dogma. Its significance for Catalonia was noted given "its outstanding Marian tradition" (" $i$ Gaudeamus in Dominio!"). This event also encouraged the production of Marian works in the Catalan language. ${ }^{17}$ The Catalan Marian groups devoted to the Moreneta would expand their range of activity in the 195os.

In spite of the hostility of the Falange, repository of ultra-Righ-

16 See, as well: No.14, March 1952; Noticiario de al Unión Diocesana de Hombres de Acción Católica, Nos.94, July-August 1951; 96, November 1951 and 97, December 1951. For the build-up to the Congreso, see La Vanguardia Española, 1-6, 8-10, 12, 13, 16, 18, 20, 22-23, 25, 27 and 30 April 1952.

${ }_{17}$ See, for example, Frassinetti and Liguori. 
tism, to the visible revival of aspects of Catalanism, the Francoist attempt at the complete extirpation of Catalan culture and the cultural submergence of Catalonia within Spain was being slowly defeated. The regime would limit itself to the control and prevention of the outbreak of "political" manifestations of this cultural revival. Representative of the advances of religious-led Catalanization through the Church were Catalan-language religious publications that attained wider diffusion. In Tarragona, Ramon Muntanyola produced the Catalan language parish bulletin, La Veu de la Parròquia until 1950, which was followed by the creation of Resso in 1950. Ressò was published eleven times before its closure due to the opposition of the Bishop of Tarragona. This short-lived publication was much more than a parish journal in the Catalan language, as it demonstrated by its change of title in June 1951 to Ressò, cróniques $i$ comentaris d'actualitat. It contained articles on culture, literature and current affairs and included contributions from prominent figures of Catalan Catholicism such as Maurici Serrahima, Carles Cardó, Carles Riba and Joan Triadú. As Muntanyola later remarked, "we can consider Ressố as a significant predecessor of Serra d'Or" (Muntanyola I4I). In May 1949 the monthly Germinabit was created as the newsletter of the Unió de l'Escolania de Montserrat (Choir Boys' Union of Montserrat). At the end of 1959 Germinabit would fuse with Serra d'Or to become Serra d'Or, Segona Epoca becoming a wide-ranging cultural and religious monthly in the Catalan language. Whilst in tone Germinàbit was distinct from proregime Catholic publications, it gave expression to a fervent Catalan Catholic viewpoint: "We have at the summit of Montserrat, a Moreneta that is so beautiful and so much our own, that it even speaks to us in Catalan" ("Rosa d'April... Guieu-nos cap al cel").

The religious Catalanization in Catalan life and the cult around the Moreneta was noted in an article by Anselm Albareda, who remarked that in 1956 there were now 10,000 women in Catalonia who bore the name Montserrat, "a fact which was unknown in previous centuries" ("Montserrat i Catalunya"). In 1958 the monastery created Qüiestions de Vida Cristiana, a Catalan language theological-cultural publication. As was noted: "Recently and quietly, and growing every day, Montserrat has begun again its editorial task, which dried up in a most violent way in 1936 " "Una nova publicació montserratina"). Until the 1960 , many of the movements of Catalan Catholicism were narrow in scope and membership, but the revival of escoltisme (the Catalan boyscout movement) was the greatest contributor to a pre-mass mobilization of the population. Through the scouts, large numbers of Catalan youth were given the opportunity to study the Catalan language, and were introduced to Catalan history and culture. The Catalan scouts closely followed the prescription of Lord Baden- 
Powell's scout movement, which he had founded in England at the height of the British Empire. The idea behind the creation of the Catalanist scouts lay with the Anglophile figure, Josep Maria Batista i Roca, who published the Manual d'Excursionisme in 1927. The following year Batista i Roca produced his scouting manifesto: "If we have been successful in ordering the anarchy that there has been in our language... why do we not also try and succeed in putting in order that chaotic attitude that exists in the Catalan young of today?" (Castells 23).

The principal figure in the reconstruction of the Catalan scouting movement in the I950s was Monsignor Antoni Batlle, for whom scouting gave the young the opportunity "to make men of them" and "to love the word of God" (Antics Escoltes). In 1948, Batlle was appointed by the Bishop of Barcelona to be responsible for the scouts within Catalonia. Although Bishop Modrego remained firmly within the orbit of Spanish National Catholicism, his tolerance of scouting and other cultural manifestations has to be seen in the light of Catholic rivalry with the "materialist" Falange as mobilizers of the young. The Catalan scouts were imbued with notions of duty, Catholicism and Catalan patriotism. Although the scouts had a great deal of protection under the "umbrella" of the Catholic Church, their activities did not escape the attention of the State, particularly the Falange. The Falange youth movement saw the scouts as not only rivals for youth mobilization, but as dangerous "separatists":

Today the groupings of the Minyons de Muntanya (lit. mountain boys) that are flowering in a multitude of religious associations of the province (of Barcelona), hastily announce themselves to be "apolitical"...Why do their members adorn themselves with a "prudent" hostility...towards the youth movements of the regime and adopt styles that are absent of all national (i.e. Spanish) spirit? (Atajo) ${ }^{18}$

The death of Monsignor Batlle in 1955 and his funeral brought about a gathering of the groupings of Catalan Catholicism. Antoni Tarner described the atmosphere at the funeral and remarked that within the sectors of Catalan Catholicism, in spite of Batlle's death, there was a feeling of "euphoria." Furthermore, the bringing together of former and present scouts was "effective for the good of the Church and the Fatherland" (Tarner). ${ }^{19}$ The following year, 1956, Abbot Escarré gave his own seal of approval to the work of Batlle. Speaking to a group of scouts, Escarré declared: "Each one of you is a young Catalan Christian and tomorrow you will be a young Catalan citizen! I recommend to you but one thing: that you be true Catalans and that

18 This was a youth publication of the Falange.

rg See also Centro Excursionista de Cataluña and El Ciervo. 
you be true Christians" (Escarré 54 ). Escarré did not see the encouragement that he gave to the scouts as an oppositional activity per se. In the same year that he paid homage to Battle and the Catalanist scout movement, he provided the introduction to a work that commemorated the Carlist militia that had fought for Franco during the Civil War (Nonell iii).

Catholic-led reconstruction also occurred in other areas. The sardana had, during the course of the late nineteenth and early twentieth century, become the Catalan national dance. During the Franco regime, it actually expanded its range and became confirmed as the national dance, displacing remaining local and regional dances that had resisted its hegemony. In the expansion of the sardana, its "civilizing" and non-"decadent" nature was constantly evoked. "When you dance the sardana, never forget that it is not like any other dance. It is not any old dance that can be danced happily and wildly...No! The sardana can only be danced if all that it represents is taken into account" (Agrupación Cultural). For Serra d'Or, "the Black Madonna has endowed our national dance with life since the Renaixença... Happy are the people that can pray by dancing" ("La Sardana a Montserrat"). Another Catholic publication noted that, in contrast to other popular dances, it puts the dancer in a position of surrender and innocence, seen as vital "not only for dancing but for living" ("La dansa més Bella"). ${ }^{2 I}$

The emergence of these entities was confirmation of the reconstruction of Catalan civil society and a public sphere. One Catalanist commented in 1955, "I am convinced... of the vitality of Catalanism...in fact I believe that today, Catalanism is...the only living force in Spain" (Fontseré). ${ }^{22}$ As has been noted, the Catalanism that had emerged by the 1950 s had re-emerged through Catholicism. It is notable that the base for the subsequent transformation of Catalanism and its revival was laid during the religious-led revival of Catalan language and culture during the 1940 .

By the end of the r950s, Catalan cultural manifestations are increasingly suffused with a Catalan Catholicism, revealing how cultural forms had been become dependent on religious patronage. However, the hoped for re-Christianization of the populace was not achieved and the Catalan people remained largely secular. However,

20 For this expansion see Ressó, Christmas 1951 and Agrupación Folklórica de Barcelona, No. 15, August 1952.

21 For other examples of this "Catholicization" of the sardana, sec Agrupación Cultural Folklorica de Barcelona, Nos.n, March and 16, September 1952 and No.21, February 1953.

22 Anonymous individual cited in Fontseré. 
given the turbulent history of Catholicism in modern Catalonia, it was striking that the Catalan anti-clerical tradition did end, a process cemented by the Church's close relations with the Catalan opposition during the 196os, including the communist opposition of the PSUC. As Nous Horitzons declared: "progressive Catholics deserve our support" ("Alguns aspects"). During the final decade of the Franco regime, churches and the monastery of Montserrat became sanctuaries for the opposition forces. Indicative of the breach made with the Franco regime, in 1963 , Abbot Escarré gave his famous interview to Le Monde criticizing the regime that would lead to his exiling to Italy (Minobis 219-222). The origins of this transformation in the Church's position within Catalanism and Catalonia's political culture is to be found in the extraordinary circumstances encountered post-1939. The Franco regime restored the Church to a position of preeminence yet the belligerent and anti-Catalan nature of Spanish National Catholicism would ensure a break with the regime would take place. Through this break with the dictatorship, the Catalan Church, from being the subject of popular rage at the start of the Civil War, would become broadly accepted as an embodiment of the nation.

ANDREW DOWLING

CARDIFF UNIVERSITY

\section{WORKS CITED}

"¡Abajo la iglesia! Treinta siglos (sic) de obscurantismo religioso envenaron las mentes del pueblo español." Solidaridad Obrera is August 1936: I.

Acedo Colunga, Felipe. Letter to Blas Pérez, is September 1951, No. 1.236, Caja 3, AGCB.

- Letter to Francisco Franco Salgado-Araujo, 8 June 195r. Agrupación Cultural Folklórica de Barcelona 37 (June 1954).

"Alguns aspects de la lluita ideològicala a Catalunya" Nous Horitzons $3(196 \mathrm{t})$.

AlvÁREZ Bolado, Alfonso. El experimento del nacional catolicismo. Madrid: Edicusa, 1976.

Antics Escoltes. (1952): iI.

Atajo I9 August 1953.

$\mathrm{BACH}$, Antoni. Retalls d'una sotana. Barcelona: Publicacions de l'Abadia de Montserrat, 1977.

BADA, Joan. Guerra civil i església catalana: la "recepció" de la guerra civil per l'església de Catalunya 1938-1953. Barcelona: Facultad de 
Teologia de Catalunya: Publicacions de l'Abadia de Montserrat, 1987.

Barrull Pelegrí, Jaime. Violència popular i justicia revolucionària: El tribunal popular de Lleida (1936-1939). Lleida: Pagès, 1995.

Boletin Informativo del XXXV Congreso Eucharistico Internacional, No.7, 9 February 1952.

CARroll, Michael P. The Cult of the Virgin Mary: Psychological Origins. Princeton. Princeton UP, 1986.

CASTELLS, Victor. Batista $i$ Roca: una vida al servei de la reconstrucció nacional. Barcelona: Rafael Dalmau, 1995.

Centro Excursionista de Cataluña. January 1956.

El Ciervo, 40 (I955).

Circular de la Junta Diocesana de Acción Católica de Barcelona. I November 1947 .

"Cirerer de claustre." Noticiario de la Unión Diocesana de Hombres de Acción Católica de Barcelona October 1949.

"Congregaciones Marianes." J.A.C.E. October 1947.

CONNELlY UlmanN, Joan. The Tragic Week: a Study of Anti-Clericalism in Spain 1875-1912. Cambridge: Harvard UP, 1968.

CONVERSI, Daniele. The Basques and the Catalans and Spain. Alternative Routes to Nationalist Mobilisation. London: Hurst, 1997.

"La dansa més bella." Ressó 8 February-March 1951.

"Después de la Liberación." Boletin Oficial Eclesiástico del Obispado de Vich u February 1939.

"Dieciséis milliones de pesetas del clero de Vich, encontradas, por camaradas nuestras, son entregadas." Solidaridad Obrera 28 July 1936: 1 .

"Discurso del abad mitrado." La Vanguardia Española 27 April 1942: 3.

"Divendres Sant." Noticiario de la Unión Diocesana de Hombres de Acción Católica de Barcelona April 1949.

EsCARRÉ, Aureli M. Montserrat és Vostre. Textos de Belascoain a Viboldone. Montserrat: Publicacions de l'Abadia, 1978.

Escutia, Angel. Letter to Franco, 4 June 1951, No. 1.236, Caja 3, Archivo del Gobierno Civil de Barcelona.

ESDAILE, Charles J. Spain in the Liberal Age. From Constitution to Civil War 1808-1939. Oxford: Blackwell, 2000.

La Federació de Joves Cristians de Catalunya. Contribució a la seva història. Barcelona: Nova Terra, 1972.

"Fiestas de la entronización de la Virgen de Montserrat. La participación de Madrid." La Vanguardia Española п April 1947: 7.

FONTSERE, Carles. Letter to Albert Manent. December 1955 in AFH Albert Manent, Caixa 25, ANC.

FrassinetTI, J. Guia de la devoció a la Mare de Déu per la joventut. Barcelona: Altes, 1950. 
Garcia GraU, Xavier. Memòria i confessió. Barcelona: PAM, 1992.

GARCIA JORDAN, Pilar. "Una església bel-ligerant? L'església catalana durant la segona república" in Catalunya i la guerra civil. Barcelona: Publicacions de l'Abadia de Montserrat, 1988. 133.

" ¡Gaudeamus in Dominio! La Asunción de María a los cielos, dogma de fe." Noticiario de la Unión Diocesana November 1950.

"Goigs a llaor de Sant Cugat." Noticiario de la Unión Diacesana de Hombres de Acción Católica de Barcelona September 1949.

GrAHAM, Helen "Against the State': A Genealogy of the Barcelona May Days (1937)." European History Quarterly 29.4 (October 1999): 485-542.

"Gratitud al Caudillo. Telegrama del Abad de Montserrat." Solidaridad Nacional 29 April 1947.

Homenaje de Cataluña liberada a su Caudillo Franco. Barcelona: Fomento de la Producción Nacional, 1940.

JoHnson, Hank. Tales of Nationalism. New Brunswick: Rutgers UP, I991.

"Jesús Infant." Noticiario de la Unión Diocesana de Hombres de Acción Católica de Barcelona February 1949.

LiguORI, Sant Alfons $\mathrm{M}^{\mathrm{a}}$ de. Les glòies de Maria. Barcelona: La Gleva, 1950.

Llopis, Arturo. "Cuna y sepulcro de Jaime Balmes." Destino 26 June 1948: 2.

MANENT I SEgIMON, Albert, Raventós i Giralt, Joseph. L'ésglésia clandestina a Catalunya durant la guerra civil (1936-1939). Barcelona: Biblioteca Serra d'Or. 1984. 97-124.

"Mensaje a los seminaristas." La Vanguardia x April 1939. ?

Minobis, Montserrat, Aureli M. Escarré. Abat de Montserrat 1946-1968. Barcelona: La Llar del Llibre, 1986.

"Montserrat i Catalunya." Germinàbit April-May 1956.

Muntayola. Ressó i95I.

"Nadal," Noticiario de la Unión Diocesana de Hombres de Acción Católica de Barcelona. December 1948.

"La necesidad de fomentar las vocaciones sacerdotales." La Vanguardia Española i April 1939: 4.

"Neguit." Noticiario de la Unión Diocesana de Hombres de Acción Católica de Barcelona October 1948.

NONELL, Salvador. Los requetés catalanes del tercio de nuestra Señora de Montserrat en la cruzada española. Barcelona: Editorial Casulleras. 1956.

"Una nova publicació montserratina: Qüestions de Vida Catalana." Germinàbit August 1958.

"L'ombra del bisbe Torras." Noticiario de la Unión Diocesana de Hombres de Acción Católica de Barcelona 30 June 1948. 
"Ombres i clavors." Noticiario de la Unión Diocesana de Hombres de Acción Católica de Barcelona November 1949.

La paraula cristiana.I (1925): 3 .

The Parliamentary Committee for Spain. Religion and Spain. Bristol, 1938.

"Pastoral del cardenal arzobispo de Tarragona." La Vanguardia Española I2 April 1947: 10.

Pérez LedesmA, Manuel. "Studies on Anti-Clericalism in Contemporary Spain." International " $\mathrm{I}$ Jornada de Estudios Obrera. Doscientos mil jóvenes obreros consumidos por el vicio exigen nuestro esfuerzo." Acción Católica i June 194r.

Perry, Nicholas, Echeverría, Loreto. Under the Heel of Mary. London: Routledge. 1988.

PINOL, Josep M. La nacionalcatolicisme a Catalunya i la resistència 1926-1966. Barcelona: Edicions 62, 1993.

Qüestions de Vida Cristiana (July 1958).

RAGUER I SUNER, Hilari (Ernest). Gaudeamus Igitur. Notes per a una bistòria del "Grup Torras i Bages." Barcelona: Publicacions de l'Abadia de Montserrat, 1999.

"Un record de librerias. 10o.0oo ejemplares de Verdaguer vendidos en un año." Destino 28 July 1945.

"El representante del Caudillo y el Cardenal del Papa presiden la brillantísima de Nuestra Señora de Montserrat." Solidaridad Nacional 29 April 1947.

Review of Social History 46 (2001): 231.

"Rosa d'April... Guie-nos cap al cel" Germinàbit April-May 1954.

RUCABADO, Ramon. La custodia del fuego. Barcelona: Balmes, 1940.

-. Iglesias en el cielo. Barcelona: Balmes, 1942.

"La Sardana a Montserrat." Serra d'Or 14 April 1955.

"Se inició la campaña de vocaciones sacerdotales." Acción Católica I February 1941.

SOlÉ I SABATÉ, Josep M., Villarroya, Joan. L'ocupació militar de Catalunya, març 1938-febrer 1939. Barcelona: L'Avenç, 1987.

- La repressió a la retaguarda de Catalunya 1936-1939. Barcelona: Publicacions de l'Abadia de Montserrat, 1989.

TARNER, Antoni. Letter. 26 October 1955 in AFH Escoltisme Català, 166 , Carpeta 9.05, Arxiu Nacional de Catalunya

"Vara Florida." Noticiario de la Unión Diocesana de Hombres de Acción Católica de Barcelona March 1949.

WARNER, Marina. Alone of all Her Sex: the Myth and Cult of the Virgin Mary. London: Picador, 1985. 